\title{
PERBANDINGAN EFEKTIVITAS BERKUMUR MENGGUNAKAN LARUTAN PROPOLIS LEBAH 12,38\% (APIS MELLIFERA) DAN KLORHEKSIDIN GLUKONAT 0,2 \% TERHADAP INDEKS PLAK
}

\author{
Dara Puspita Harvi ${ }^{1}$, Nur Indrawati Lipoeto ${ }^{2}$ Hidayati $^{1}$ \\ ${ }^{\mathbf{1}}$ Fakultas Kedokteran Gigi Universitas Andalas \\ ${ }^{2}$ Fakultas Kedokteran Universitas Andalas
}

\begin{abstract}
Dental plaque is the primary etiologic in the development of caries and periodontal disease. Chlorhexidine gluconate $0.2 \%$ is the mouthwash that is widely used and effective in reducing dental plaque index, but this mouthwash is chemical with few side effects if used for long periods. Propolis is a bee product that has a high content of flavonoids antibacterial and has many benefits in health and has minimal side effects because it belongs to natural product. This study aims to determine differences in the gargling effectiveness using Chlorhexidine gluconate $0.2 \%$ and bee propolis solution $12.38 \%$ (Apis mellifera) in reducing dental plaque index. The method used in this research was a clinical experimental with the design of one group pretest and posttest. The subjects consisted of 20 students of MA DR. Abd. Ahmad PGAI Padang. Dental plaque index was measured using PHP plaque index before and after gargling using the solution of bee propolis (Apis mellifera) $12.38 \%$ and chlorhexidine gluconate $0.2 \%$. The data of research findings were analyzed using paired T-test $(p<0.05)$. The results show that the mean of plaque index reduction of gargling using the solution of bee propolis $12.38 \%$ (Apis mellifera) is 0,88 with the standard deviation of \pm 0.66 and the mean of plaque index of gargling using Chlorhexidine gluconate $0.2 \%$ is 1.56 with the standard deviation of \pm 0.79 . There is a significant difference with p value $=0.005(p<0.05)$. Chlorhexidine gluconate $0.2 \%$ shows higher reduction, but this mouthwash is the chemical with few side effects, while the solution of bee propolis $12.38 \%$ (Apis mellifera) is a natural substance that is safer to use.
\end{abstract}

Keywords: chlorhexidine gluconate $0.2 \%$, bee propolis, dental plaque index

Affiliasi penulis: ${ }^{1}$ Fakultas Kedokteran Gigi Universitas Andalas Korespondensi: hidayati, email: hidayati@dent.unand.ac.id

\section{PENDAHULUAN}

Prevalensi penyakit gigi dan mulut merupakan salah satu indikator Indeks Pembangunan Kesehatan Masyarakat (IPKM) yang menggambarkan tingkat pembangunan kesehatan pada masyarakat Indonesia. ${ }^{1}$ Kesehatan gigi dan mulut di Indonesia masih memerlukan perhatian yang serius oleh tenaga kesehatan, hal ini dapat dilihat dari tingkat kesadaran masyarakat akan pentingnya kesehatan gigi dan mulut yang masih rendah.
Sebanyak $25,9 \%$ penduduk Indonesia mempunyai masalah gigi dan mulut. Terdapat $31,1 \%$ yang menerima perawatan dan pengobatan dari tenaga medis gigi (perawat gigi, dokter gigi atau dokter gigi spesialis), sementara $68,9 \%$ lainnya tidak dilakukan perawatan. $^{2}$

Menurut hasil RISKESDA tahun 2013, indeks $D M F-T$ Indonesia sebesar 4,6 yang berarti kerusakan gigi penduduk Indonesia 460 buah gigi per 100 orang, sedangkan indeks $D M F-T$ untuk provinsi Sumatera Barat sebesar 4,7.2 Hasil ini menunjukan tidak tercapainya indeks DMF-T yang sesuai 
dengan standar yang ditetapkan oleh WHO (World Health Organization) yaitu sebesar 3 pada usia 12 tahun. ${ }^{3}$

Penyakit periodontal merupakan masalah kesehatan gigi dan mulut yang memiliki prevalensi cukup tinggi di masyarakat dengan prevalensi masalah periodontal pada semua kelompok umur di Indonesia adalah 96,58\%. ${ }^{4}$ Pengobatan penyakit periodontal di Indonesia menempati posisi ke-6 (enam) dari 13 jenis pengobatan gigi yang sering dilakukan, yaitu pencabutan gigi tetap, pembersihan karang gigi, pencabutan gigi sulung, pengobatan pulpa/tumpatan sementara, tumpatan gigi tetap. Di provinsi Sumatera Barat terdapat 2.127 kali pengobatan penyakit periodontal dari total keseluruhan provinsi di Indonesia yaitu sebanyak 83.531 kali. $^{8}$

$$
\text { Penyakit periodontal terjadi }
$$
karena adanya akumulasi plak. Mikroorganisme yang berkoloni di dalam plak akan mengeluarkan produk produknya, seperti lipopolisakarida yang dapat merusak jaringan periodontal. ${ }^{5}$ Plak gigi merupakan akumulasi dari bakteri yang terdapat di permukaan gigi dalam bentuk biofilm. Biofilm terbentuk ketika bakteri mengikat secara selektif pada pelikel yang merupakan lapisan terluar dari gigi dan terdiri dari protein dan makromolekul lain yang ditemukan di dalam rongga mulut. Pelikel berisi komponen dari saliva, cairan sulkus gingiva, dan bakteri. Pelikel memiliki banyak fungsi, berperan sebagai pelumas permukaan gigi untuk membantu proses mengunyah, berbicara dan juga bertindak sebagai penghalang semipermeabel antara enamel dan lingkungan mulut dalam mengatur proses remineralisasi dan demineralisasi. ${ }^{6}$

Plak dapat dihilangkan dengan kontrol plak. Kontrol plak merupakan pengambilan bakteri plak dan pencegahan menumpuknya plak pada gigi dan permukaan gingiva yang berdekatan yang merupakan cara yang efektif untuk perawatan dan pencegahan gingivitis dan periodontitis. Kontrol plak dapat dilakukan dengan dua cara, yaitu secara mekanik dan kimiawi. Kontrol plak secara mekanik dilakukan dengan menyikat gigi dan menggunakan dental flossing. Kontrol plak secara kimiawi dapat dilakukan dengan berkumur bahan antimikroba dan pasta gigi. Proses berkumur bertujuan untuk membersihkan mulut dari sisa-sisa makanan yang memiliki agen antibakteri untuk mengurangi akumulasi plak. ${ }^{7}$ Jenis bahan yang digunakan dalam obat kumur terbagi menjadi dua jenis, bahan obat kumur kimia dan herbal yang mempunyai kelebihan dan kekurangan masing-masing. Obat kumur secara luas digunakan sebagai tambahan untuk menjaga kebersihan mulut dan dalam 
pengiriman bahan aktif pada gigi dan gusi. Kemampuan obat kumur dalam membersihkan mulut mempengaruhi pembentukan plak dan inflamasi gingiva. $^{9}$

Klorheksidin merupakan salah satu contoh obat kumur yang mengandung bahan kimia dan banyak digunakan sebagai antiseptik spektrum luas dalam kedokteran dan kedokteran hewan klinis sejak 1953. Obat ini sudah tersedia di Eropa lebih dari 25 tahun dan telah berhasil digunakan dalam bidang kedokteran gigi dalam kurun waktu tersebut. ${ }^{10}$ Efek samping klorheksidin adalah pewarnaan coklat pada gigi dan lidah yang melekat secara kuat pada permukaan gigi atau restorasi dan jika penggunaannya lebih dari empat minggu, maka pewarnaan yang timbul sulit untuk dihilangkan, terjadi pembentukan kalkulus supragingiva, dan perubahan pada pengecapan. Pada anak-anak sering terjadi efek samping berupa pengelupasan epitel mulut, tetapi tidak menunjukkan terjadinya resistensi bakteri. ${ }^{10}$

Produk herbal sudah digunakan untuk tujuan pengobatan tradisional di seluruh dunia selama ribuan tahun. Banyak dari bahan herbal yang memiliki sifat farmakologi, seperti antimikroba, antiinflamasi, antisitostatik, dan lain lain yang telah diakui untuk pengobatan. Berbagai produk herbal dan ekstrak yang sering digunakan seperti jambu, delima, propolis, teh hijau, cranberi, anggur dan berbagai produk herbal lainnya dapat digunakan sebagai obat kumur. Obat kumur dengan bahan herbal dapat diracik dengan mudah dan digunakan secara aman yang bertujuan untuk peningkatan kesehatan gigi umum pada masyarakat. ${ }^{20}$

Dari berbagai obat kumur herbal yang memiliki kandungan antimikroba yang telah dijelaskan diatas peneliti mengambil salah satu bahan herbal untuk dibandingkan efektivitasnya, yaitu obat kumur propolis. Propolis merupakan salah satu sumber zat gizi alami dan nutraceutical yang berasal dari substrat resin yang dikumpulkan lebah dari sari tunas daun dan kulit batang tanaman yang dicampur dengan enzim dan lilin dari sarang lebah. Bahan herbal ini sudah digunakan sejak 300 SM sebagai obat untuk menyembuhkan kulit yang luka karena mempunyai efek antiinflamasi. dan mempunyai kandungan gizi mikro yang bernilai tinggi, yaitu vitamin (A, B, dan C), mineral (Ca, $\mathrm{Mg}, \mathrm{Na}, \mathrm{Fe}, \mathrm{Mn}, \mathrm{Cu}$, dan Zn), serta enzim suksinat dehydrogenase. Flavonoid dan turunan asam sinamat merupakan kandungan zat aktif utama yang dimiliki oleh propolis. ${ }^{11}$ Kandungan aktif yang juga diketahui terkandung dalam propolis adalah polifenol (flavonoid, asam 
fenolat, dan esternya), terpenoid, steroid, dan asam amino. ${ }^{12}$ Flavonoid merupakan zat yang diketahui banyak terdapat pada tumbuh-tumbuhan dan mempunyai efek antioksidan dalam melumpuhkan radikal bebas. Propolis diketahui mempunyai kandungan flavonoid yang tinggi. ${ }^{12}$

Ada banyak aplikasi klinis dan maanfaat propolis dalam pengobatan kedokteran gigi, seperti pengobatan pada ulserasi dikarenakan pemakaian gigi tiruan, stomatitis, bau mulut, periodontal pocket/abses, dan obat kumur. Propolis dipakai juga untuk pengobatan lichen planus, infeksi jamur kandida, angular cheilitis, xerostomia, ulkus traumatik ortodontik, erupsi gigi, pulp capping, dan restorasi sementara. ${ }^{24}$ Berdasarkan penelitian sebelumnya telah terbukti bahwa propolis mempunyai efek antibakteri terhadap bakteri Streptococcus mutan, Staphylococcus aureus, Porphyromonas gingivalis, Prevotella intermedia, Tannerella forsythia, Fusobacterium nucleatum dan terhadap bakteri penyebab plak dan infeksi lainnya. ${ }^{11,14,17}$ Propolis juga memiliki efek antijamur terhadap Candida albicans. Penelitian laboratorium yang dilakukan oleh Elizabeth pada tahun 2014 yang membandingkan efektivitas propolis $12,38 \%$ dan Klorheksidin glukonat 0,2\% terhadap biofilm Porphyromonas gingivalis menunjukan bahwa ekstrak propolis $12,38 \%$ mampu menghambat biofilm Porphyromonas gingivalis lebih tinggi dibandingkan klorheksidin glukonat $0,2 \%$. Porphyromonas gingivalis merupakan salah satu bakteri yang berperan dalam pembentukan plak pada gigi. ${ }^{14}$

Berdasarkan permasalahan diatas penelitian ini bertujuan untuk mengetahui efektivitas berkumur larutan propolis lebah (Apis mellifera) 12,38\% dan klorheksidin glukonat $0.2 \%$ terhadap penurunan indeks plak gigi.

\section{METODE}

Jenis Penelitian ini digunakan adalah eksperimen dengan desain pre and post test. Teknik sampling yang digunakan adalah simple random sampling, yaitu setiap anggota atau unit dari populasi mempunyai kesempatan yang sama untuk diseleksi sebagai sampel. Besar sampel dalam penelitian ini adalah 20 orang yang berkumur larutan propolis lebah (Apis mellifera) $12,38 \%$ dan berkumur klorheksidin glukonat $0.2 \%$.

Prosedur penelitian hari pertama melakukan survey awal untuk memilih subjek/responden yang sesuai dengan kriteria inklusi penelitian dengan menyebarkan angket siswa/i Madrasah Aliyah DR. H Abdullah Ahmad PGAI Kota Padang. Hari kedua penelitian 
dilakukan dua perlakuan sebelum dan setelah berkumur klorheksidin glukonat $0.2 \%$. Untuk mengurangi efek pasta gigi, subjek diinstruksikan menyikat gigi menggunakan sikat gigi dan pasta gigi dengan jenis dan teknik yang sama pada malam sebelum dimulainya penelitian pada pukul 22.00 WIB.

Pada hari kedua penelitian dimulai pada pukul 06.30 WIB dilakukan dilakukan pengukuran indeks plak pada gigi yang telah ditentukan menurut kriteria penilaian indeks plak PHP (Personal Hygiene Performance) dengan cara mewarnai seluruh permukaan gigi dengan menggunakan disclosing solution gel dan menghitung nilai indeks plak sebelum perlakuan. Setelah itu subjek diintruksikan untuk berkumur klorheksidin glukonat $0.2 \%$ sebanyak $10 \mathrm{ml}$ selama 30 detik. Setelah berkumur dilakukan penelitian indeks plak dengan cara yang sama dengan pengukuran sebelum perlakuan untuk mendapatkan indeks plak setelah perlakuan.

Pada hari ketiga Penelitian dimulai pada pukul 06.30 WIB dilakukan dilakukan pengukuran indeks plak pada gigi yang telah ditentukan menurut kriteria penilaian indeks plak PHP (Personal Hygiene Performance) dengan cara mewarnai seluruh permukaan gigi dengan menggunakan disclosing solution gel dan menghitung nilai indeks plak sebelum perlakuan. Setelah itu subjek diintruksikan untuk berkumur larutan propolis lebah (Apis mellifera) $12,38 \%$ sebanyak $10 \mathrm{ml}$ selama 30 detik. Setelah berkumur dilakukan penelitian indeks plak dengan cara yang sama dengan pengukuran sebelum perlakuan untuk mendapatkan indeks plak setelah perlakuan.

\section{HASIL DAN PEMBAHASAN}

Tabel 1. Perbedaan Indeks Plak Sebelum dan Sesudah Berkumur Larutan Propolis lebah (Apis mellifera) 12,38\% dan berkumur Klorheksidin

Glukonat $0,2 \%$

\begin{tabular}{|c|c|c|c|c|c|}
\hline \multirow[b]{2}{*}{ Variabel } & \multirow[b]{2}{*}{$\mathbf{n}$} & \multicolumn{2}{|c|}{$\begin{array}{c}\text { Propolis } \\
\text { lebah (Apis } \\
\text { mellifera) } \\
12,38 \%\end{array}$} & \multicolumn{2}{|c|}{$\begin{array}{c}\text { Klorheksidin } \\
\text { Glukonat } \\
\mathbf{0 , 2 \%}\end{array}$} \\
\hline & & $\begin{array}{l}x \pm \\
S D\end{array}$ & $p$ & $\begin{array}{l}\mathrm{X} \pm \\
\text { SD }\end{array}$ & $p$ \\
\hline $\begin{array}{l}\text { Indeks } \\
\text { plak } \\
\text { pretest } \\
\text { Indeks } \\
\text { plak } \\
\text { posttest }\end{array}$ & 20 & $\begin{array}{c}3,12 \\
\pm \\
0,96 \\
2,24 \\
\pm \\
0,84\end{array}$ & 0,000 & $\begin{array}{c}3,7 \pm \\
0,78 \\
2,13 \pm \\
0,99\end{array}$ & $0,003^{*}$ \\
\hline
\end{tabular}

Tabel 2. Perbedaan Efektivitas Penurunan Indeks Plak Antara Berkumur Larutan Propolis Lebah (Apis mellifera) 12,38\% dan Klorheksidin Glukonat 0,2\% $(n=20)$

\begin{tabular}{lll}
\hline \multicolumn{1}{c}{ Variabel } & $\boldsymbol{x} \pm \boldsymbol{S D}$ & $\boldsymbol{p}$ \\
\hline Larutan propolis lebah & $0,88 \pm$ & \\
$12,38 \%$ (Apis mellifera) & 0,96 & 0,005 \\
Klorheksidin glukonat $0,2 \%$ & $1,56 \pm$ & \\
\hline
\end{tabular}

Tabel 2 diatas menunjukkan penurunan indeks plak berkumur menggunakan klorheksidin glukonat $0,2 \%$ lebih tinggi dibandingkan larutan propolis lebah (Apis mellifera) 12,38\%. Hasil uji statistik dengan Independen $T$ - 
Test didapatkan nilai $\mathrm{p}=0,005(\mathrm{p}<0,05)$ yang berarti terdapat perbedaan bermakna dari selisih rata - rata indeks plak subjek penelitian berkumur larutan propolis lebah (Apis mellifera) 12,38\% dan klorheksidin glukonat $0,2 \%$.

Propolis dapat mempunyai efek antibakteri dengan cara mencegah pembelahan sel sehingga menghasilkan bahan yang disebut sebagai Pseudo Multicellular Streptococcus (PMS). Propolis dapat mengacaukan sitoplasma, membran sitoplasma dan dinding sel yang menyebabkan bacteriolisis parsial dan menghambat sintesa protein. Sudah terbukti bahwa mekanisme kerja propolis terhadap sel bakteri sangat kompleks. ${ }^{25}$

Penghambatan dalam pembentukan plak gigi terjadi akibat mekanisme anti bakterial propolis lebah. Hal ini ditunjukkan oleh penelitian yang dilakukan oleh Ardo Sabir tahun 2005 yang menyebutkan bahwa flavonoid yang terdapat pada propolis dari lebah mampu menghambat pertumbuhan Streptococcus mutans secara in vitro. ${ }^{29}$ Penelitian yang dilakukan Vidya Dodwad pada tahun 2012 menyebutkan bahwa propolis dapat menurunkan indeks plak dan menjaga kesehatan gingiva. ${ }^{20}$ Penelitian laboratorium yang dilakukan oleh Elizabeth pada tahun 2014 yang didapatkan hasil efektivitas propolis $12,38 \%$ terhadap biofilm
Porphyromonas gingivalis menunjukan bahwa ekstrak propolis 12,38 \% mampu menghambat biofilm Porphyromonas gingivalis. ${ }^{14}$

Kandungan aktif yang juga diketahui terkandung dalam propolis adalah polifenol (flavonoid, asam fenolat, dan esternya), terpenoid, steroid, dan asam amino. Propolis diketahui mempunyai kandungan flavonoid yang tinggi. ${ }^{12}$ Flavonoid merupakan suatu senyawa fenol yang tersebar luas pada hampir semua tumbuhan tingkat tinggi, kecuali algae. Penelitian secara in vivo dan in vitro menunjukkan bahwa flavonoid mempunyai aktivitas biologis dan farmakologis, antara lain sebagai antibakteri. Flavonoid mempunyai aktivitas antibakteri karena flavonoid mempunyai kemampuan berinteraksi dengan DNA bakteri. Hasil interaksi tersebut menyebabkan terjadinya kerusakan permeabilitas dinding sel bakteri, mikrosom dan lisosom. ${ }^{34}$

Propolis diketahui memiliki beberapa efek farmakologis yang penting, antara lain sifat antibakteri baik terhadap bakteri gram positif maupun Gram negatif. Sifat antibakteri dari propolis ini bukan semata-mata disebabkan karena senyawa tunggal, namun karena efek sinergis dari beberapa senyawa yang terdapat pada propolis yang bersifat antibakteri yakni: flavonoid, asam ferulat, ester asam 
fenol, asam sinamat, dan berbagai ester asam kafeat. ${ }^{29}$

Mekanisme

klorheksidin

glukonat $0,2 \%$ dalam menghambat pembentukan plak dikarenakan memiliki kemampuan untuk mengadakan ikatan dengan kelompok asam anionik glikoprotein saliva, sehingga perlekatan pelikel akuid yang diperlukan untuk kolonisasi bakteri plak terhambat, mengadakan ikatan dengan lapisan polisakarida yang menyelubungi bakteri sehingga absorbsi bakteri permukaan gigi atau pelikel akuid terhambat, mengendapkan faktor-faktor aglutinasi asam yang ada dalam saliva dan menggantikan kalsium yang diperlukan sebagai perekat bakteri pembentuk massa plak. Klorheksidin glukonat $0,2 \%$ juga memiliki efek bakterisida karena terikatnya molekul kationiknya dengan anionik bakteri yang akan mempengaruhi dinding sel bakteri dan selanjutnya mengganggu keseimbangan osmotis sel. ${ }^{7}$

Teori yang telah ada sudah banyak diteliti pada penelitian sebelumnya terhadap efektivitas klorheksidin glukonat $0,2 \%$. Penelitian Sulistiyani tahun 2001, subyek penelitian yang berkumur dengan klorheksidin 0,2 \% menunjukkan jumlah koloni bakteri Streptococcus sp paling sedikit, karena klorheksidin merupakan derivat dari bisguanid bisfenol yang bersifat bakterisidal baik terhadap kuman gram negatif maupun positif. 33 Penelitian laboratorium yang dilakukan oleh Elizabeth pada tahun 2014 yang didapatkan hasil efektivitas klorheksidin glukonat $0,2 \%$ terhadap biofilm Porphyromonas gingivalis menunjukan bahwa klorheksidin glukonat $0,2 \%$ mampu menghambat biofilm Porphyromonas gingivalis. ${ }^{14}$

Klorheksidin merupakan derivat dari bisguanid bisfenol yang bersifat bakterisidal baik terhadap kuman gram negatif maupun positif. bisguanid pada klorheksidin mengandung 2 muatan positif yang mempunyai afinitas terhadap permukaan bermuatan negatif, misalnya dinding sel mikroorganisme, polisakarida ekstraseluler mikroorganisme, hidroksiapatit, pelikel, plak dan mukosa mulut. ${ }^{33}$

Klorheksidin mampu mengubah struktur permukaan sel, sehingga menyebabkan hilangnya keseimbangan osmotik, selanjutnya terjadi penonjolan membran sitoplasma, terbentuk vesikel dan keluarnya sitoplasma dapat menghambat perbaikan sel dan akhirnya terjadi kematian sel. Kerugian penggunaan klorheksidin sebagai obat kumur adalah terjadinya pewarnaan pada gigi dan lidah serta menyebabkan iritasi pada mukosa. ${ }^{32}$ 


\section{SIMPULAN}

Khlorheksidin glukonat $0,2 \%$ dan larutan propolis lebah 12,38\% (Apis mellifera) efektif dalam menurunkan indeks plak. Khlorheksidin glukonat $0,2 \%$ mampu menurunkan indeks plak lebih tinggi dibandingkan larutan propolis lebah 12,38\% (Apis mellifera).

\section{KEPUSTAKAAN}

1. Kementrian Kesehatan Republik Indonesia. Indeks Pembangunan Kesehatan Masyarakat, Jakarta. 2010.

2. Balai Penelitian dan Pengembangan Kesehatan

Kementrian Kesehatan Republik Indonesia, 2013. Riset Kesehatan Dasar, Jakarta.

3. Who Oral Health, Oral Health Surveillance. [Online]. http://www.who.int/oral_health/ac tion/information/surveillance/en/, Diakses pada tanggal 29 November 2014

4. Tampubolon, Nurmala Situmorang. Dampak Karies Gigi dan Penyakit Periodontal Terhadap Kualitas Hidup

5. Newman M, Takei H, Klokkevold P, Carranza F, Carranza's Clinical Periodontology Ninth Edition. St. Louis, Missouri: Saunders Company, Elsevier Inc. 2006
6. Hannig M, Joiner A: The structure, function and properties of the acquired pellicle. Monographs Oral Science. 2006

7. Diah. Kontrol plak kemikal dalam pencegahan gingivitis dan periodontitis. Periodontic Journal, Vol 1, No 1. Januari 2012. 1-6

8. Penelitian Ditjen Pelayanan Medik Departemen Kesehatan Republik Indonesia. 2008. Profil Kesehatan. Jakarta

9. Ozan F, Sumer Z, Polat ZA, Er K, Ozan U, Deger O. Effect of Mouthrinse Containing Propolis on Oral Microorganisms and Human Gingival Fibroblasts. Eur J Dent 2007

10. Eley B.M. Antibacterial agents in the control of supragingival plaque - a review. British Dental Journal. 1999.

11. Ahuja V, Ahuja A. Apitherapy-A sweet approach to dental DiseasesPart II: Propolis. J Acad Adv Dent Res. 2011; May; 2(2):1-7.

12. Eliza H, Hardinsyah, Noorwati S, Ahmad S, Made A, dan Yahdiana H. Bioactive compounds and nutrients content of Indonesian and Brazilian propolis. JGP, Vol 7 , No. 1. 2012.

13. Ann Felton. Basic Guide to Oral Health Education and promotion. 
2009. Wiley-Blackwell, Oxford, London.

14. Elizabeth $\mathrm{P}$, Ari S, Ira W. Efektivitas ekstrak Propolis $12,38 \%$ dan Chlorhexidine gluconate $0,2 \%$ terhadap biofilm Porphyromonas gingivalis. Conservative Dentistry Jurnal. Vol. 4, No.2. 2011.11-14

15. Gaurav S, Namita L, Renu S. A Review on dental plaque. Lachoo Memorial College of Science and Technology. 2014. India

16. Putri MA, Herijulianti E, Nurjannah N. Ilmu pencegahan penyakit jaringan keras dan jaringan pendukung gigi. Jakarta: EGC,2009.

17. Santos VR. Propolis: Alternative Medicine for the Treatment of Oral Microbial Diseases. Alternative Medicine. 2012; 133 169.

18. Mathur, Setu, Tanu Mathur, Rahul Srivastava, and Rohit Khatri. "Chlorhexidine: The Gold Standard in Chemical Plaque Control." National Journal of Physiology, Pharmacy \& Pharmacology 1.2 (2011): 45-50.

19. Cappelli DP, Mobley CC. Prevention in Clinical Oral Health Care. St. Louis: Mosby Elsevier, 2008: 14-26
20. Dodwad V, Kukreja BJ. Herbal Mouthwashes A Gift of Nature. International Journal of Pharma and Bio Sciences; 2012

21. Manson JD, Eley BM. Buku Ajar Periodonti. Alih bahasa, Anastasia S. Ed ke-2. Jakarta: Hipokrates, 1993.

22. Chetrus V. Dental Plaque: Classification, formation, and identification. International Journal of Medical Dentistry. 2013;3(2):139-143.

23. Dalimunthe SH. Periodonsia. Medan: USU Press, 2001

24. Dodwad V, Kukreja BJ. Propolis mouthwash: A new beginning. J Indian Soc Periodontal. 2011 AprJun; 15(2): 121-125

25. Bambang S, Ni Made M, Eko BK, Mangestuti A. Chemical composition and activity of propolis as anti microbial from Malang East Java. J. Peneliti Med Eksakta .2009 Apr.

26. HV Amith, Anil V Ankola, L Nagesh. Effect of Oil Pulling on Plaque and Gingivitis.J Oral Health Comm Dent 2007; Vol 1:12-18

27. Sastroasmoro, Sudigdo. Dasar dasar Metodologi Penelitian Klinis. Sagung Seto, Jakarta. 2011 28. Eliza H, Hardinsyah, Noorwati S, Ahmad S, Made A, dan Yahdiana 
H. Bioactive compounds and nutrients content of Indonesian and Brazilian propolis. JGP, Vol 7, No. 1. 2012.

29. Ardo Sabir. Respons inflamasi pada pulpa gigi tikus setelah aplikasi ekstrak etanol propolis (EEP). Majalah Kedokteran Gigi. Vol 38. 2005

30. Fernanda C RL, Andreza M FA, Indri N, Elisa MAG, Josimeri H, Carlos ASC. Toxicity of chlorhexidine on odontoblast-like cells. J Appl Oral Sci. 2010; 18(1): 50-8.

31. Lauren O. Bakaletz, Developing animal models for polymicrobial diseases

http://www.nature.com/nrmicro/jo urnal/v2/n7/fig_tab/nrmicro928_F 3.html, Juli 2004. Diakses pada 1 April 2014.

32. Laksminingsih R. Pengaruh Kumur dengan Teh Hitam, Povidon Iodium $1 \%$,

Chlorhexidine $0,1 \%$ terhadap Jumlah Koloni bakteri dalam Saliva. Dalam Majalah Kedokteran Gigi. Volume 34. Nomer 3a. Agustus 2001. 2001. Surabaya: FKG Unair, 456 - 459.

33. Sulistiyani. Uji Toksisitas Obat Kumur Klorheksidin terhadap Kultur Sel. 2001. Dalam Majalah Kedokteran Gigi. Volume 34.
Nomer 3a. Agustus 2001.

Surabaya: FKG Unair, 221 - 223.

34. Sabir, A. Pemanfaatan Flovanoid di Bidang Kedokteran Gigi. Dalam Majalah Kedokteran Gigi. 2003. Edisi Khusus Temu Ilmiah Nasional III. Surabaya: FKG Unair, $81-87$.

35. Nurin Aisyiyah Listyasari. Pengaruh Pasta Gigi Dengan Kandungan Propolis Terhadap Pembentukan Plak Gigi. 2012. Semarang: Universitas Diponegoro 